\title{
Forouzan R. Shafie
}

\section{forouzanshafie@gmail.com}

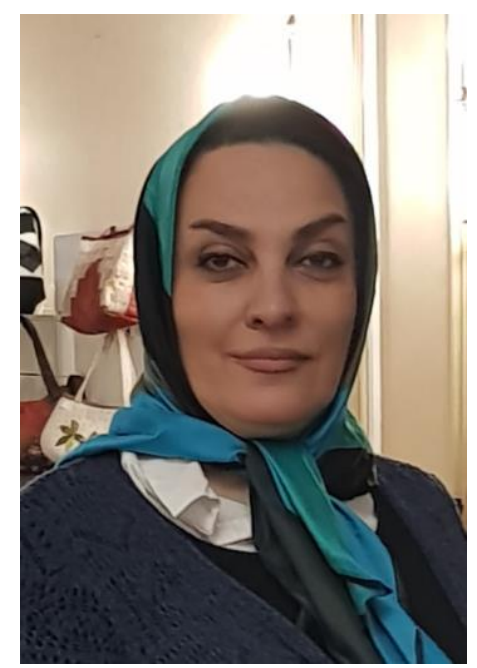

\section{Department of Visual Arts, Faculty of Art and Architecture, Guilan University, Iran}

Forouzan borne on $23^{\text {rd }}$ of April 1970 in Iran. She is currently working for Department of Visual Arts, Faculty of Art and Architecture, Guilan University. She is working and living in Tehran, Iran. She earned a bachelor of painting in 1994 and her master degree in 1996 from Al-Zahra University in Iran and then started her career in the maintenance of Iranian murals.

Later on she got another bachelor of interior design from interior design center at the University of Tehran. As university professor she taught at different universities like: Al-Zahra University, University Jihad in Tehran University of Art, Tehran University of Technology, Amool Faculty, Guilan University and Free School of Visual Arts Mana affiliated with Iranian Technical and Professional Organization. She published many articles in different Iranian interior design journals.

She already held many painting exhibitions in Iran and more than fifteen countries, as well as she won the Protection Award for the Hite of the Arts in Vienna and Rome on the Peace and happiness. She got a special award from the jury in Vienna and Rome Art biennials

Currently, she is working as free Iranian artist since 2015. In 2016 she published her work on how to conserve fungi through art? In the first international conference on fungal conservation in MENA. She started to use new attractive tool to raise national and international awareness on fungal conservation by drawing of fungi in many attractive portraits as ancient Egyptians documented them everywhere. She participated with her portraits to attract young mycologists in MENA and to apply a new tool for conserving fungi (http://fungiofegypt.com/Forouzan.html). She designed the logos of the $2^{\text {nd }}$ International Conference on Mycology in MENA (http://fungiofegypt.com/Conference/2018/) and the $4^{\text {th }}$ National Fungus day of Egypt (http://www.fungiofegypt.com/20Feb/).

She is working right now as executive director of internal management and coordination at the Free School of Visual Arts (Mana Art) in Iran. 